\title{
Therapeutic Hypothermia for Refractory Status Epilepticus
}

\author{
Frederick A. Zeiler, Kaitlin J. Zeiler, Jeanne Teitelbaum, Lawrence M. Gillman, \\ Michael West
}

\begin{abstract}
Background: Our goal was to perform a systematic review of the literature on the use of therapeutic hypothermia for refractory status epilepticus (RSE) and its impact on seizure control. Methods: All articles from MEDLINE, BIOSIS, EMBASE, Global Health, HealthStar, Scopus, Cochrane Library, the International Clinical Trials Registry Platform (inception to May 2014), reference lists of relevant articles, and gray literature were searched. The strength of evidence was adjudicated by two independent reviewers, using both the Oxford and GRADE methodology. Results: Overall, 13 studies were identified, with 10 manuscripts and 3 meeting abstracts. A total of 40 patients were treated. The common target temperature was 33 degrees Celsius, sustained for a median 48 hours. Patients displayed a $62.5 \%, 15 \%$ and $22.5 \%$ rate of seizure cessation, seizure reduction, and failure of treatment respectively. External cooling was utilized in the majority of cases. Deep venous thrombosis, coagulopathy and infections were the commonly reported complications. Two ongoing clinical trials were identified. Conclusions: Oxford level 4, GRADE D evidence exists to support the use of therapeutic hypothermia to control seizures in RSE. Further prospective study is warranted.
\end{abstract}

RÉSUMÉ: Hypothermie thérapeutique dans l'état de mal épileptique réfractaire. Contexte: Le but de cette étude était d'effectuer une revue systématique de la littérature au sujet de l'utilisation de l'hypothermie thérapeutique comme traitement de l'état de mal épileptique réfractaire (MER) et son impact sur le contrôle des convulsions. Méthode: Nous avons recherché les articles pertinents dans MEDLINE, BIOSIS, EMBASE, Global Health, HealthStar, Scopus, Cochrane Library, the International Clinical Trials Registry Platform (du début à mai 2014), les listes de références des articles pertinents et la littérature grise. La puissance des données a été évaluée par deux reviseurs indépendants au moyen de la méthode d'Oxford et de la méthode GRADE. Résultats: Au total, 13 études ont été identifiées, dont 10 manuscrits et 3 résumés de présentations à des congrès. En tout, 40 patients ont été traités ainsi. La température cible générale était de $33^{\circ}$ Celsius, maintenue pendant une médiane de 48 heures. L'hypothermie a induit un arrêt de la crise chez $62,5 \%$ des patients, une diminution des convulsions chez $15 \%$ et s'est soldée par un échec chez 22,5\% des patients. Dans la majorité des cas, le refroidissement externe a été utilisé. Les complications les plus fréquemment rapportées étaient la thrombose veineuse profonde, la coagulopathie et l'infection. Deux études cliniques en cours ont été identifiées. Conclusions: Des données de grade 4 d'Oxford, de niveau D, existent en faveur de l'utilisation de l'hypothermie thérapeutique pour contrôler les crises dans le MER. Il est justifié de procéder à des études prospectives sur ce mode de traitement.

Keywords: Critical Care, Epilepsy, Epilepsy - Expermental, Hypothermia, Intensive Care, Neurocritical Care doi:10.1017/cjn.2015.31

Can J Neurol Sci. 2015; 42: 221-229

Systemic therapeutic hypothermia (TH) is a medical therapy with a wide variety of clinical applications. ${ }^{1-4}$ From post cardiac arrest, ${ }^{1}$ to neonatal hypoxemic encephalopathy, ${ }^{2}$ to intracranial pressure control in traumatic brain injury (TBI) ${ }^{3}$ and stroke, ${ }^{4} \mathrm{TH}$ has been trialed.

Some of the potential neurological benefits of $\mathrm{TH}$ include: reduction in cerebral metabolic rate and oxygen consumption, reduction in free radical formation, inhibition of apoptosis, ${ }^{5}$ and slowing of action potential propagation. ${ }^{6}$ It is with these mechanisms and more, that $\mathrm{TH}$ has the potential to impact seizure control in the setting of refractory status epilepticus (RSE). ${ }^{6,7}$

To date, the majority of literature on TH for RSE focuses on animal models. ${ }^{6,8}$ However, a small number of manuscripts exist on the application of $\mathrm{TH}$ in human subjects with RSE with promising results. $^{9-21}$
Our goal was to perform of systematic review of the literature on the use of systemic TH in the setting of RSE, in order to comment on its effectiveness in seizure control.

\section{Materials AND Methods}

A systematic review using the methodology outlined in the Cochrane Handbook for Systematic Reviewers ${ }^{22}$ was conducted. The data was reported following the Preferred Reporting Items for

From the Section of Neurosurgery (FAZ, MW); Section of General Surgery (LMG), Department of Surgery; Section of Critical Care Medicine, Department of Medicine, University of Manitoba, Winnipeg; Section of Neurocritical Care (KJZ, JT); Section of

Neurology (JT), Montreal Neurological Institute, McGill, Montreal, Canada. ReCeived July 9, 2014. Final Revisions Submitted OCtober 15, 2014. Correspondence to: Frederic A. Zeiler, GB-1 820 Sherbrook Street, Winnipeg, MB, Canada, R3A 1R9. Email: umzeiler@cc.umanitoba.ca 
Systematic Reviews and Meta-Analyses (PRISMA). ${ }^{23}$ The review questions and search strategy were decided upon by the primary author and supervisor.

\section{Search Question, Population, Inclusion and Exclusion Criteria}

The question posed for systematic review was: What is the effectiveness of systemic TH on control of RSE in humans? All studies, prospective and retrospective of any size based on human subjects were included. The reason for an all-inclusive search was based on the small number of studies of any type identified by the primary author during a preliminary search of MEDLINE.

The primary outcome measure was electrographic seizure control. Secondary outcome measures were patient outcome (if reported), and adverse effects of the $\mathrm{TH}$.

Inclusion criteria were: All studies including human subjects whether prospective or retrospective, all study sizes, any age category, and the use of systemic TH for seizure control in RSE. Exclusion criteria were: animal and non-English studies, any study not describing the seizure response to $\mathrm{TH}, \mathrm{TH}$ for resistant epilepsy (i.e. must describe the use of TH in status epilepticus), and focal cortical hypothermia treatment for RSE or resistant epilepsy.

\section{Search Strategy}

MEDLINE, BIOSIS, EMBASE, Global Health, HealthStar, SCOPUS, and Cochrane Library from inception to May 2014 were searched using individualized search strategies for each database. The search strategy for MEDLINE can be seen in Appendix A of the supplementary material, with a similar search strategy utilized for the other databases. In addition, the World Health Organizations International Clinical Trials Registry Platform was searched looking for studies planned or underway.

As well, meeting proceedings for the past five years looking for ongoing and unpublished work based on $\mathrm{TH}$ for seizures were examined. The meeting proceedings of the following professional societies were searched: Canadian Neurological Sciences Federation (CNSF), American Association of Neurological Surgeons (AANS), Congress of Neurological Surgeons (CNS), European Neurosurgical Society (ENSS), World Federation of Neurological Surgeons (WFNS), American Neurology Association (ANA), American Academy of Neurology (AAN), European Federation of Neurological Science (EFNS), World Congress of Neurology (WCN), American Epilepsy Society (AES), International League Against Epilepsy (ILAE), Society of Critical Care Medicine (SCCM), Neurocritical Care Society (NCS), World Federation of Societies of Intensive and Critical Care Medicine (WFSICCM), American Society for Anesthesiologists (ASA), World Federation of Societies of Anesthesiologist (WFSA), Australian Society of Anesthesiologists, International Anesthesia Research Society (IARS), Society of Neurosurgical Anesthesiology and Critical Care (SNACC), Society for Neuroscience in Anesthesiology and Critical Care, and the Japanese Society of Neuroanesthesia and Critical Care (JSNCC).

Finally, reference lists of any review articles or systematic reviews on seizure management were reviewed for relevant studies on $\mathrm{TH}$ for seizure control.

\section{Study Selection}

Utilizing two reviewers, a two-step review of all articles returned by our search strategies was performed. First, the reviewers independently screened all titles and abstracts of the returned articles to decide if they met the inclusion criteria. Second, full text of the chosen articles was then assessed to confirm if they met the inclusion criteria and that the primary outcome of seizure control was reported in the study. Any discrepancies between the two reviewers were resolved by a third party.

\section{Data Collection}

Data was extracted from the selected articles and stored in an electronic database. Data fields included: patient demographics, type of study (prospective or retrospective), number of patients, details of TH administration and management, how many other anti-epileptic drugs (AEDs) were utilized prior to implementation of $\mathrm{TH}$, degree of seizure control, adverse effects, and patient outcome.

\section{Quality of Evidence Assessment}

Assessment of the level of evidence for each included study was conducted by two independent reviewers, utilizing the Oxford criteria $^{24}$ and the Grading of Recommendation Assessment Development and Education (GRADE) criteria ${ }^{25-30}$ for level of evidence. We elected on utilizing two different systems to grade level of evidence as these two systems are amongst the most commonly used. We believe this would allow a larger audience to follow our systematic approach in the setting of unfamiliarity with a particular grading system.

The Oxford criterion consists of a five level grading system for literature. Level 1 is split into subcategories $1 \mathrm{a}, 1 \mathrm{~b}$, and $1 \mathrm{c}$ which represent a systematic review of randomized control trials (RCT) with homogeneity, individual RCT with narrow confidence interval, and all or none studies respectively. Oxford level 2 is split into $2 \mathrm{a}, 2 \mathrm{~b}$, and $2 \mathrm{c}$ representing systematic review of cohort studies with homogeneity of data, individual cohort study or low quality RCT, and outcomes research respectively. Oxford level 3 is split into $3 \mathrm{a}$ and $3 \mathrm{~b}$ representing systematic review of casecontrol studies with homogeneity of data and individual casecontrol study respectively. Oxford level 4 represents case-series and poor cohort studies. Finally, Oxford level 5 represents expert opinion.

The GRADE level of evidence is split into 4 levels: A, B, C and D. GRADE level A represents high evidence with multiple high quality studies having consistent results. GRADE level B represents moderate evidence with one high quality study, or multiple low quality studies. GRADE level C evidence represents low evidence with one or more studies with severe limitations. Finally, GRADE level D represents very low evidence based on either expert opinion or few studies with severe limitations.

Any discrepancies between the grading of the three reviewers were resolved via a third party.

\section{Statistical Analysis}

A meta-analysis was not performed in this study due to the heterogeneity of data within the articles and the presence of a small number of low quality retrospective studies. 


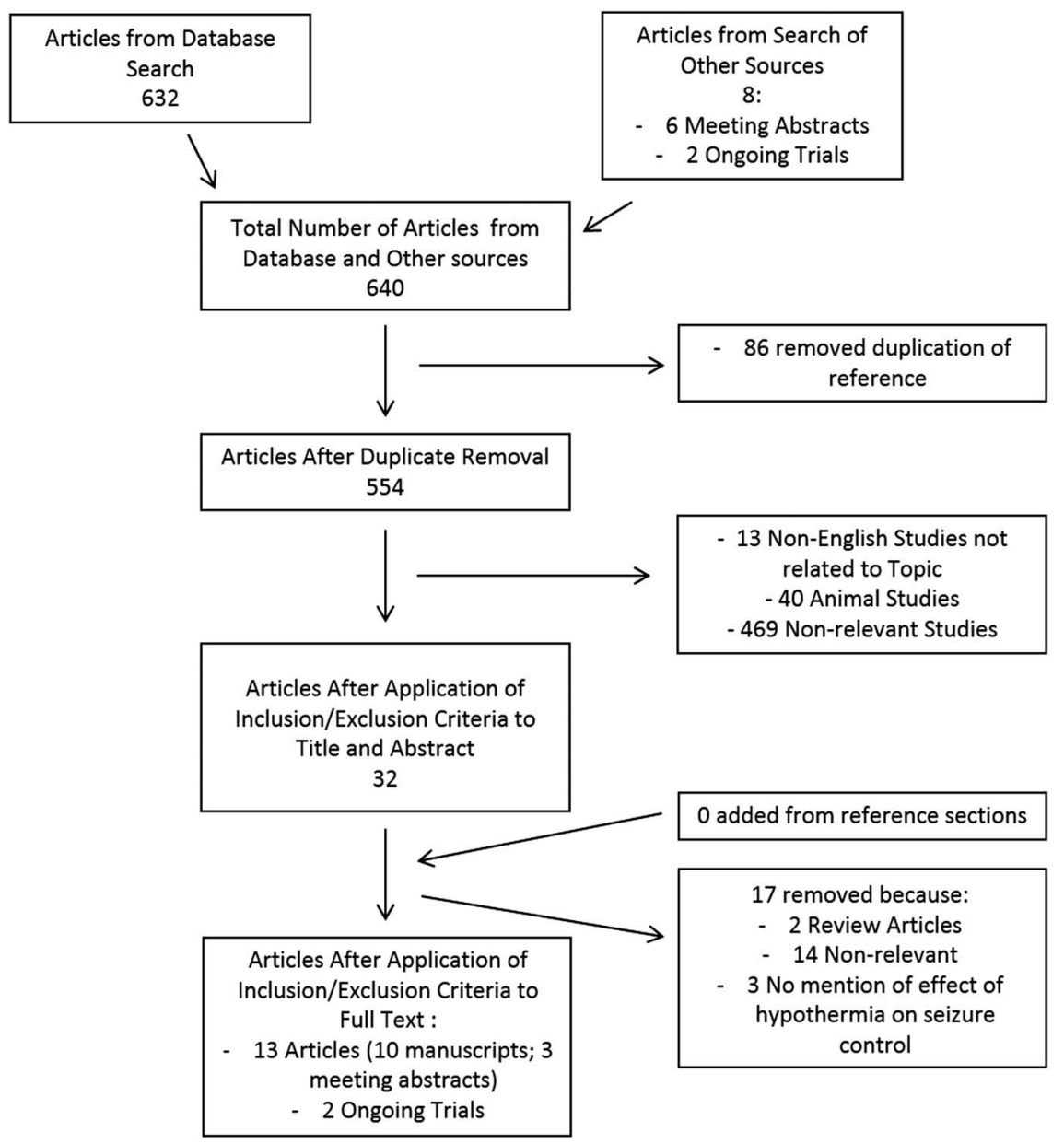

Figure 1: Flow Diagram of Search Results

\section{RESULTS}

The results of the search strategy across all databases and other sources are summarized in Figure 1. After removal of duplicates a total of 554 articles were identified, with 546 from the database search, 6 from the search of published meeting proceedings, and 2 ongoing clinical trials identified in the World Health Organization (WHO) database. By applying the inclusion/ exclusion criteria to the title and abstract of the articles, we identified 32 articles that fit these criteria. Of the 32 identified, 27 were from the database search, 3 were from published meeting proceedings, and 2 were ongoing clinical trials. Applying the inclusion/exclusion criteria to the full text documents, only 13 articles were eligible for inclusion in the systematic review, with 10 from database and 3 from meeting proceeding sources. Given the lack of published data, the 2 ongoing clinical trials are listed within for completeness. The 17 articles that were excluded either did not report details around the administration of TH for seizure control, or because they were review articles. Reference sections from these review articles were searched for any other articles missed in the database search, with none being identified. Of the 13 articles included in the review, ${ }^{9-21}$ all were original studies. Three articles were published meeting abstracts. ${ }^{11,14,20}$
All studies were retrospective: eight were retrospective case series $^{10,11,13,14,16,18,20,21}$ and the remaining five were retrospective case reports. ${ }^{9}, 12,15,17,19$ The retrospective case series were all single center reviews. Five articles described the use of inhaled anesthetic in adults. ${ }^{9-11,17,21}$ Six studies described pediatric patients. ${ }^{12,13,15,16,18,19}$ Two studies failed to mention patient age. ${ }^{14,20}$

Across all studies, a total of 40 patients were studied utilizing systemic TH for control of their RSE (mean: 3.1 patients/study; range: 1-7 patients/study). Fourteen patients were pediatric (age range: 4 months to 18 years). Eighteen patients were adult (age range: 19 to 75 years). A variety of underlying etiologies for RSE existed in both the adult and pediatric populations. Eight patients, in two studies, were of unknown age..$^{14,20}$

Study demographics and patient characteristics for all studies can be seen in Table 1, while treatment characteristics and seizure outcome are reported in Table 2.

\section{TH Treatment Characteristics}

Within the 13 studies identified utilizing systemic $\mathrm{TH}$ for control of RSE, the technique of achieving hypothermia involved: external cooling blanket, ${ }^{9,12,13,16,18,19,21}$ endovascularly, ${ }^{10}$ and unknown. ${ }^{11,14,15,17,20}$ One study utilized concurrent thiopental 


\section{Table 1: Study Characteristics and Patient Demographics}

\begin{tabular}{|c|c|c|c|c|c|c|c|c|}
\hline Reference & $\begin{array}{c}\text { Number of Patients } \\
\text { Treated with } \\
\text { Hypothermia } \\
\end{array}$ & Study Type & Study Setting & $\begin{array}{l}\text { Article } \\
\text { Location }\end{array}$ & Mean age & Etiology of Seizures & $\begin{array}{l}\text { Mean \# AED } \\
\text { Prior to } \\
\text { Hypothermia }\end{array}$ & $\begin{array}{l}\text { Mean Time until } \\
\text { Hypothermia }\end{array}$ \\
\hline Cereda et al. $^{9}$ & 1 & $\begin{array}{l}\text { Retrospective } \\
\text { Case Report }\end{array}$ & ICU & Manuscript & 21 & Cryptogenic & 9 & 2 months \\
\hline Corry et al. ${ }^{10}$ & 4 & $\begin{array}{r}\text { Retrospective } \\
\text { Case Series }\end{array}$ & ICU & Manuscript & 64.3 yrs (range: $54-75$ ) & $\begin{array}{l}\text { Cryptogenic (1); limbic encephalitis } \\
\text { (2); hepatic encephalopathy (1) }\end{array}$ & 5 (range: $4-6$ ) & Unknown \\
\hline Czeisler et al. ${ }^{11}$ & 7 & $\begin{array}{l}\text { Retrospective } \\
\text { Case Series }\end{array}$ & ICU & $\begin{array}{l}\text { Meeting } \\
\text { Abstract }\end{array}$ & $44+/-16 \mathrm{yrs}$ & $\begin{array}{l}\text { Cryptogenic, Encephalitis Not } \\
\text { Specified }\end{array}$ & 4 & 2 days \\
\hline Elting et el. ${ }^{12}$ & 1 & $\begin{array}{l}\text { Retrospective } \\
\quad \text { Case Report }\end{array}$ & ICU & Manuscript & 5 months & Hemimegalencephaly & 8 & Unknown \\
\hline Guilliams et al. ${ }^{13}$ & 5 & $\begin{array}{r}\text { Retrospective } \\
\text { Case Series }\end{array}$ & ICU & Manuscript & $\begin{array}{l}87.2 \text { months (range: } \\
5-180 \text { months) }\end{array}$ & $\begin{array}{l}\text { Unknown (3); Alpers-Huttenlocher } \\
\text { Syndrome (1); NMDA } \\
\text { encephalitis (1) }\end{array}$ & 7.6 (range: $6-9$ ) & Unknown \\
\hline Hakimi et al. ${ }^{14}$ & 5 & $\begin{array}{l}\text { Retrospective } \\
\text { Case Series }\end{array}$ & ICU & $\begin{array}{l}\text { Meeting } \\
\text { Abstract }\end{array}$ & Unknown & $\begin{array}{l}\text { Post-Cardiac Arrest (3); Post } \\
\text { Trauma (2) }\end{array}$ & Unknown & Unknown \\
\hline Ito et al. ${ }^{15}$ & 1 & $\begin{array}{l}\text { Retrospective } \\
\quad \text { Case Report }\end{array}$ & ICU & Manuscript & $11 \mathrm{yrs}$ & Anti Glu-Epsilon-2 encephalitis & 5 & 10 days \\
\hline Lin et al. ${ }^{16}$ & 2 & $\begin{array}{l}\text { Retrospective } \\
\text { Case Series }\end{array}$ & ICU & Manuscript & $\begin{array}{l}7.5 \text { yrs (range: } \\
4.5-10.5 \text { ) }\end{array}$ & $\begin{array}{l}\text { Febrile Infection-related Epilepsy } \\
\text { Syndrome (FIRES) }\end{array}$ & 6 & $\begin{array}{l}\text { Case } 1: \\
8 \text { hrs } \\
\text { Case } 2: \\
12 \text { hrs }\end{array}$ \\
\hline Missert et al. ${ }^{17}$ & 1 & $\begin{array}{r}\text { Retrospective } \\
\text { Case Report }\end{array}$ & ICU & Manuscript & $67 \mathrm{yrs}$ & CJD & 6 & 11 days \\
\hline Orlowski et al. ${ }^{18}$ & 3 & $\begin{array}{l}\text { Retrospective } \\
\text { Case Series }\end{array}$ & ICU & Manuscript & 11.6 yrs (range: $6-18$ ) & $\begin{array}{l}\text { Viral Encephalitis (1); Cryptogenic } \\
\text { (1); Reye's Syndrome (1) }\end{array}$ & 5.6 (range: 4-9) & Unknown \\
\hline Shein et al. ${ }^{19}$ & 1 & $\begin{array}{l}\text { Retrospective } \\
\quad \text { Case Report }\end{array}$ & ICU & Manuscript & 4 months & SCN1A Mutation & 8 & 6 days \\
\hline Svoronos et al. ${ }^{20}$ & 3 & $\begin{array}{r}\text { Retrospective } \\
\text { Case Series }\end{array}$ & ICU & $\begin{array}{l}\text { Meeting } \\
\text { Abstract }\end{array}$ & Unknown & Unknown & Unknown & Unknown \\
\hline Vastola et al. ${ }^{21}$ & 6 & $\begin{array}{l}\text { Retrospective } \\
\text { Case Series }\end{array}$ & $\mathrm{ICU}$ & Manuscript & 43.3 yrs (range: $16-69$ ) & $\begin{array}{l}\text { Cryptogenic (1); Post-SAH (1); } \\
\text { Iatrogenic (1); CLL (1); } \\
\text { Meningo-encephalitis (1); } \\
\text { SBE (1) }\end{array}$ & 1.8 (range: $1-3$ ) & $\begin{array}{l}28.1 \text { hrs (range: } \\
2.5-48 \text { hours) }\end{array}$ \\
\hline
\end{tabular}

$\mathrm{ICU}=$ intensive care unit, NMDA = n-methyl d-aspartate, yrs = years, hrs = hours, AED = anti-epileptic drugs, CJD = Creutzfeldt Jakob Disease, CLL = chronic lymphocytic leukemia,

$\mathrm{SBE}=$ subacute bacterial endocarditis 
Table 2: Treatment Characteristics, Seizure Response, and Outcome

\begin{tabular}{|c|c|c|c|c|c|c|c|c|}
\hline Reference & Hypothermia Technique & $\begin{array}{l}\text { Temperature } \\
\text { Target (degrees } \\
\text { Celcius) }\end{array}$ & $\begin{array}{l}\text { Duration of } \\
\text { Hypothermia }\end{array}$ & $\begin{array}{l}\text { Time to } \\
\text { Target Temp }\end{array}$ & $\begin{array}{l}\text { Time for } \\
\text { Rewarming }\end{array}$ & $\begin{array}{l}\text { Electrographic Seizure } \\
\text { Response }\end{array}$ & Adverse Effects to Hypothermia & Patient Outcome \\
\hline Cereda et al. $^{9}$ & $\begin{array}{l}\text { Cooling Blanket } \\
\text { Temp Measured: } \\
\text { Not stated }\end{array}$ & 34 & Unknown & Unknown & Unknown & Transient Seizure Resolution & Bowel Perforation & Ongoing Seizures \\
\hline Corry et al. ${ }^{10}$ & $\begin{array}{l}\text { Endovascular Catheter } \\
\text { Temp Measured: IVC }\end{array}$ & 33 (range: $31-35$ ) & $\begin{array}{l}36.9 \text { (range: } \\
20-61 \mathrm{hrs)}\end{array}$ & $\begin{array}{l}5.5 \text { (range: } \\
1.5-10 \mathrm{hrs})\end{array}$ & $\begin{array}{l}31.5 \mathrm{hrs} \\
\text { (range: } \\
1.5- \\
45.5 \mathrm{hrs} \text { ) }\end{array}$ & $\begin{array}{l}\text { Burst suppression (3), seizure } \\
\text { cessation (1) } \\
\text { Seizures after Rewarm: } 2 / 4\end{array}$ & $\begin{array}{l}\text { Acidosis (4), DVT (3), UTI (2), } \\
\text { Peritonitis (1), Arrhythmias (2) }\end{array}$ & $\begin{array}{l}\text { Survived (2), } \\
\text { GOS }=1 \text { (2) }\end{array}$ \\
\hline Czeisler et al. ${ }^{11}$ & Not stated & Unknown & Unknown & Unknown & Unknown & $\begin{array}{l}5 / 7(71 \%) \text { improvement in } \\
\text { Seizure activity }\end{array}$ & None & Not stated \\
\hline Elting et al. ${ }^{12}$ & $\begin{array}{l}\text { Cooling Blanket } \\
\text { Temp Measured: } \\
\text { Tympanic }\end{array}$ & 36 & 4 days & Unknown & Unknown & Seizure cessation & None & Not stated \\
\hline $\begin{array}{l}\text { Guilliams } \\
\text { et al. }{ }^{13}\end{array}$ & $\begin{array}{l}\text { Cooling Blanket } \\
\text { Temp Measured: } \\
\text { Bladder }\end{array}$ & 33 (range: $32-34$ ) & $\begin{array}{l}46 \text { hrs (range: } \\
24-120 \text { hrs) }\end{array}$ & $\begin{array}{l}4.8 \mathrm{hrs} \text { (range: } \\
1-13 \mathrm{hrs} \text { ) }\end{array}$ & 0.5 degree/day & $\begin{array}{l}\text { Burst Suppression (3) in } \\
2-3 \text { hours, seizure } \\
\text { cessation (2) }\end{array}$ & $\begin{array}{l}\text { 3/5 patients = Infection (2), } \\
\text { electrolyte imbalance (1), } \\
\text { coagulopathy (2); hemodynamic } \\
\text { instability (1); ischemic } \\
\text { bowel (1) }\end{array}$ & $\begin{array}{c}\mathrm{GOS}=4(2) \\
\mathrm{GOS}=2(1) \\
\mathrm{GOS}=1(2)\end{array}$ \\
\hline Hakimi et al. ${ }^{14}$ & Not stated & 33 & Unknown & Unknown & Unknown & $\begin{array}{l}0 / 3(0 \%) \text { of Cardiac Arrest } \\
\text { patients responded } \\
2 / 2(100 \%) \text { of Post-trauma } \\
\text { patients had seizure control }\end{array}$ & None & $\begin{array}{l}\text { Complete seizure } \\
\text { control in Post-TBI. } \\
\text { Not effective in post } \\
\text { cardiac arrest. }\end{array}$ \\
\hline Ito et al. ${ }^{15}$ & Not stated & Unknown & 10 days & Unknown & Unknown & $\begin{array}{l}\text { Mild reduction in number of } \\
\text { seizures }\end{array}$ & None Described & $\begin{array}{l}\text { Recurrent Seizures, } \\
\text { GOS }=3\end{array}$ \\
\hline Lin et al. ${ }^{16}$ & $\begin{array}{l}\text { Cooling Blanket } \\
\text { Temp Measured: } \\
\text { Bladder }\end{array}$ & 33 in both & $\begin{array}{l}\text { Case } 1: 5 \text { days } \\
\text { Case } 2: 3 \text { days }\end{array}$ & Unknown & $\begin{array}{l}\text { Case } 1: 3 \text { days } \\
(1 \text { degree/day) } \\
\text { Case } 2: 4 \text { days } \\
(1 \text { degree/day })\end{array}$ & $\begin{array}{l}\text { Case 1: Seizure Cessation } \\
\text { Case 2: Seizure Cessation }\end{array}$ & $\begin{array}{l}\text { Case 1: Hypokalemia } \\
\text { Case 2: None }\end{array}$ & $\begin{array}{l}\text { Both Mild deficits } \\
(\mathrm{GOS}=4)\end{array}$ \\
\hline Missert et al. ${ }^{17}$ & Not Stated & $32-33$ & 2 days & Unknown & 48 hours & Seizure Cessation & None & $\begin{array}{l}\text { Complete Seizure } \\
\text { Control }\end{array}$ \\
\hline $\begin{array}{l}\text { Orlowski } \\
\text { et al. }{ }^{18}\end{array}$ & $\begin{array}{l}\text { Cooling Blanket + } \\
\text { Thiopental Infusion } \\
\text { Temp Measured: PA } \\
\text { Catheter }\end{array}$ & $30-31$ & $\begin{array}{l}2.6 \text { days } \\
\text { (range: } \\
2-3 \text { ) }\end{array}$ & Unknown & $\begin{array}{l}1 \text { degree every } \\
3-4 \mathrm{hrs}\end{array}$ & Burst Suppression in All & None & $\begin{array}{l}\mathrm{GOS}=4(2) \\
\mathrm{GOS}=5(1)\end{array}$ \\
\hline Shein et al. ${ }^{19}$ & $\begin{array}{l}\text { Cooling Blanket and } \\
\text { Cooled Ventilator Gas } \\
\text { Temp Measures: Rectal }\end{array}$ & $33-34$ & $43 \mathrm{hrs}$ & $1.5 \mathrm{hrs}$ & $\begin{array}{l}0.5 \text { degree } \\
\text { every } \\
2-4 \mathrm{hrs}\end{array}$ & Seizure Cessation & None & $\mathrm{GOS}=3$ \\
\hline $\begin{array}{l}\text { Svoronos } \\
\text { et al. }^{20}\end{array}$ & Not Stated & Unknown & Unknown & Unknown & Unknown & No response & Unknown & $\begin{array}{l}\text { GOS = 1 (1) } \\
\text { Unknown (2) }\end{array}$ \\
\hline Vastola et al. ${ }^{21}$ & $\begin{array}{l}\text { Cooling Blanket } \\
\text { Temp Measured: } \\
\text { Not stated }\end{array}$ & $32-36$ & $\begin{array}{l}15.2 \mathrm{hrs} \\
\quad \text { (range: } \\
11-40 \mathrm{hrs} \text { ) }\end{array}$ & Unknown & Unknown & $\begin{array}{l}\text { Seizure Cessation in All } \\
\text { Seizure after rewarm in } 1 \\
(16.7 \%)\end{array}$ & None & Unknown \\
\hline
\end{tabular}

hrs $=$ hours, $\mathrm{IVC}=$ inferior vena cava, DVT $=$ deep venous thrombosis, $\mathrm{UTI}=$ urinary tract infection, $\mathrm{PA}=$ pulmonary artery, TBI = traumatic brain injury, GOS $=$ Glasgow Outcome Score. 
infusions during their hypothermia protocol, ${ }^{18}$ while another utilized cooled ventilator gas in addition to external cooling. ${ }^{19}$

The target temperature for TH therapy varied across studies, with a range from 30 to 36 degrees Celsius. The most common target temperature reported was 33 degrees Celcius. Bladder temperature was the most common site of measurement. The time to reach target temperature was only reported in three studies, ${ }^{10,13,19}$ with a mean of 3.9 hours (range: 1 to 13 hours). Similarly, the duration of $\mathrm{TH}$ at target temperature ranged from 11 to 240 hours (mean $=89.0$ hours, median $=67.2$ hours). ${ }^{10,12,13,15-19,21}$ Finally the mean rewarming period was also variable within the six studies in which it was reported, ${ }^{10,13,16-19}$ with a range from 31.5 to 84 hours (mean $=54.5$ hours, median $=48$ hours). ${ }^{10,16,17}$ Furthermore, a rate of rewarming was quoted from 0.5 to 1 degree Celcius every three hours to daily. ${ }^{13,16,18,19}$

Duration of treatment prior to implementation of systemic $\mathrm{TH}$ was documented in seven studies, ranging from 2.5 hours to two months $($ mean $=11.4$ days, median $=4$ days), with patients on various numbers of AEDs prior to $\mathrm{TH}$, ranging from one to nine $($ mean $=6.0$, median $=6)$. The majority of patients were likely on intravenous anesthetic drugs, though it was not clear within the reports for the majority of studies included in the review. Treatment characteristics for the adult studies can be seen in Table 2 .

\section{Seizure Response}

Seizure control with TH was documented as excellent (burst suppression or absence of seizure activity electrographically) in 25 of $40(62.5 \%)$ patients. The electroencephalogram (EEG) monitoring utilized was not mentioned in the majority of cases. Reduction in seizure frequency, or a partial response, was documented in six $(15 \%)$ of patients. Finally, failure of treatment response occurred in nine $(22.5 \%)$ patients.

After optimization of other AED's, acute recurrence of seizures upon rewarming occurred in three (7.5\%) patients and appeared temporally related to the patients return to normothermia.

No correlation between target temperature and seizure response could be determined. Similarly, given the heterogeneous pathology leading to RSE in the patient identified, we are unable to comment on the effectiveness of $\mathrm{TH}$ for specific pathology.

\section{Adverse Effects of TH}

Adverse effects were seldom described within the 13 articles reviewed. Four studies reported complications during the patient's intensive care unit (ICU) course, that may or may not be attributable to TH treatment. ${ }^{9,10,13,16}$ Giulliams et al ${ }^{13}$ and Corry et al ${ }^{10}$ described complicated patient ICU courses with the following complications: deep venous thrombosis (three patients), infections (five patients), non-hemodynamically significant arrhythmias (two patients), ischemic/perforated bowel (one patient), acidosis (four patients), and electrolyte disturbances (one patient). Cereda et $\mathrm{al}^{9}$ and Lin et $\mathrm{al}^{16}$ reported bowel perforation in one patient and hypokalemia in one patient, respectively. Based on the complexity and duration of critical illness in the patients identified in the review, it is difficult to know if the complications described can be attributed to $\mathrm{TH}$ alone.

\section{Outcome}

Patient outcome was reported in most studies, with some documentation in 8 of the 13 articles. Five manuscripts failed to document patient functional outcome. ${ }^{11,12,14,17,21}$

The overall outcome of the patients was variable, and recorded in only 15 patients. Glasgow Outcome Score (GOS) was calculated in those 15 patients with adequate data available. A GOS of $1,2,3,4$, or 5 occurred in five, one, two, six, and one patient(s) respectively.

Only five patients were reported as deceased. ${ }^{10,13,20}$ The majority of patients suffered moderate to severe disability. Often there was failure to document functional status, and focus on seizure control was the only outcome reported. Patient outcomes can be seen in Table 2 .

\section{Level of Evidence for TH}

Based on two independent reviewers, there were a total of 13 studies reviewed with all representing Oxford level 4 evidence supporting the trend to seizure improvement or control with systemic TH in RSE. Similarly, within the adult and pediatric population all studies met the criteria for GRADE D level of evidence, very low evidence, in support of the use of systemic TH for RSE.

Overall we can recommend Oxford level 4 and GRADE D evidence for the use of systemic TH for RSE. Summary of the level of evidence can be seen in Table 3 .

\section{Trials Ongoing}

Through our search of the WHO International Clinical Trials Registry Platform we identified two ongoing prospective trials utilizing systemic $\mathrm{TH}$ for status epilepticus. ${ }^{31,32}$

First, there is a French based prospective single arm study ${ }^{31}$ looking at moderate hypothermia therapy for convulsive status epilepticus in patients 18 years or older. The goal recruitment is 270 patients, with enrollment having begun in 2010. Primary outcome is functional status at three months. Secondary outcomes are: length of hospital stay, length of ICU stay, mortality, and incidence of functional sequelae. Currently, enrollment is suspended.

Second, a Chinese based prospective randomized trial ${ }^{32}$ looking at intravenous anesthetic in combination with $\mathrm{TH}$ for patients 14 years or older in RSE, currently receiving benzodiazepines and one other AED. The goal recruitment is 40 patients; 20 in the treatment arm, and 20 in the control arm. Enrollment began in January 2013 and is ongoing. Primary outcomes are: clinical and (or) EEG termination of seizures, decrease of seizures, recurrence of seizures, mortality at three months, GOS score at three months, and post-status epilepticus symptomatic epilepsy at three months. Secondary outcomes are: change in EEG during hypothermia, length of ICU stay, and length of hospital stay.

\section{Discusson}

Systemic TH poses a potential treatment option for RSE. The anti-epileptic activity of hypothermia therapy is based on a variety of changes at the molecular level. ${ }^{6}$ First, alteration in potassium ion exchange via sodium-potassium pumps has been demonstrated with hypothermia, impeding action potential propagation. ${ }^{33}$ Second, hypothermia can alter glutamate binding affinity 
Table 3: Oxford and GRADE Level of Evidence

\begin{tabular}{|c|c|c|c|}
\hline Reference & Study Type & Oxford $^{24}$ Level of Evidence & GRADE $^{25-30}$ Level of Evidence \\
\hline Cereda et al. & Retrospective Case Report & 4 & $\mathrm{D}$ \\
\hline Corry et al. & Retrospective Case Series & 4 & $\mathrm{D}$ \\
\hline Czeisler et al. & Retrospective Case Series & 4 & $\mathrm{D}$ \\
\hline Elting et al. & Retrospective Case Report & 4 & $\mathrm{D}$ \\
\hline Guilliams et al. & Retrospective Case Series & 4 & $\mathrm{D}$ \\
\hline Hakimi et al. & Retrospective Case Series & 4 & $\mathrm{D}$ \\
\hline Ito et al. & Retrospective Case Report & 4 & $\mathrm{D}$ \\
\hline Lin et al. & Retrospective Case Series & 4 & $\mathrm{D}$ \\
\hline Missert et al. & Retrospective Case Report & 4 & $\mathrm{D}$ \\
\hline Orlowski et al. & Retrospective Case Series & 4 & $\mathrm{D}$ \\
\hline Shein et al & Retrospective Case Report & 4 & $\mathrm{D}$ \\
\hline Svoronos et al. & Retrospective Case Series & 4 & $\mathrm{D}$ \\
\hline Vastola et al. & Retrospective Case Series & 4 & $\mathrm{D}$ \\
\hline
\end{tabular}

and reduce glutamate mediated excitotoxicity. ${ }^{34}$ It has also been linked to a reduction in glutamate release. ${ }^{34}$ Finally, cooling has been demonstrated to reduce synaptic vesicle release, thus reducing neurotransmission and epileptic activity. ${ }^{35}$

One of the major limiting factors to implementation of TH is its complications. Complications of systemic TH include, but are not limited to: venous thrombosis, increased infection rates, cardiac arrhythmias, electrolyte disturbances, and coagulopathy. ${ }^{6}$ Such complications of treatment are seen in the literature on TH for other neurological pathology, outside of RSE. ${ }^{1-4}$

Given the small number of studies in existence quoting the use of systematic TH for RSE, ${ }^{9-21}$ we elected to perform a systematic review of the literature to determine its effectiveness on seizure control. In addition we wished to provide a reference article for those deciding to trial TH therapy in the setting of RSE. Through our review we identified 13 articles, ${ }^{9-21} 10$ manuscripts and 3 meeting proceedings utilizing systemic TH to control refractory seizures. A total of 40 patients were described in these articles with 18 being adult, 14 pediatric, and 8 were of unknown age. All of the studies were retrospective case reports/series. Intravascular cooling was utilized in one study ${ }^{10}$, while seven studies utilized external cooling blankets. ${ }^{9,12,13,16,18,19,21}$ Five studies failed to document their technique of achieving systemic TH. ${ }^{11,14,15,17,20}$ The common target temperature was 33 degrees Celsius, as measured by bladder temperatures. This was achieved over a mean of 3.9 hours, and maintained for a median of 48 hours. Rewarming was typically by 0.5 to 1 degree over a median of 48 hours. Seizure control (burst suppression or absence of seizures electrographically) with systemic TH occurred in $62.5 \%$, while reduction in the number of seizures occurred in another $15 \%$. Overall $22.5 \%$ of patients reviewed demonstrated no seizure response to systemic $\mathrm{TH}$ and were deemed failures of treatment. In the secondary outcomes, adverse events were reported in four studies, with two studies quoting significant complications. ${ }^{10,13}$ The commonly reported adverse events were: acidosis, deep venous thrombosis, and infections. However, the complications may not entirely be related to $\mathrm{TH}$ alone and may reflect the severity of the critical illness in general. Unfortunately, patient outcome data was too sparingly documented for any strong conclusion. Overall, $12.5 \%$ of patients were reported as deceased. The remaining outcomes reported were heterogeneous, with the majority displaying moderate to severe disability. All studies were an Oxford level 4, GRADE D level of evidence supporting improvement in seizure control with systemic TH for RSE. A meta-analysis was not possible given the heterogeneous, retrospective nature of the majority of studies available.

Important trends can be seen within our review. First, we documented a $62.5 \%$ seizure cessation and $15 \%$ seizure reduction rates in the studies identified. For patients with RSE, a $77.5 \%$ chance of some degree of seizure response is impressive, thus reinforcing systemic $\mathrm{TH}$ as a viable option in RSE. A cautionary note, however; it is suspected that most of these patients were receiving intravenous anesthetic agents in concert with $\mathrm{TH}$, thus the seizure response reported may reflect the combination of therapies on board at the time. Second, the preferred technique for $\mathrm{TH}$ in the review is external cooling. This is important, since the newer endovascular devices are expensive, require technical expertise for placement and are not as readily available in most centers compared to cooling blankets. However, we are unable to comment on whether one method is superior to another at this time. Third, the target temperature of 33 degrees Celsius seems to be common target in the studies identified. No correlation between target temperature and seizure control could be identified. Fourth, despite a small number of patients displaying seizure recurrence on rewarming, it is important to emphasize that $\mathrm{TH}$ is a bridge to optimization of oral AEDs, similar to intravenous sedatives and volatile inhalational anesthetics. Fifth, complications related to TH treatment cannot be underestimated. Despite only four studies documenting complications, two displayed severe complications. ${ }^{10,13}$ Given the complexity of the critical illness in this patient population, it is difficult to know if all complications described can be solely attributed to systemic TH. Finally, two prospective trials utilizing $\mathrm{TH}$ for seizures have been identified, both of which will hopefully shed further light on the utility of systemic $\mathrm{TH}$ in RSE. 
Our review has significant limitations. First, the small number of studies identified, all with small patient populations, makes it difficult to generalize to all RSE patients. Second, the retrospective heterogeneous nature of the data (both patient disease characteristics and treatment regimens) makes it difficult to perform a meaningful meta-analysis, resulting in a strictly descriptive analysis. Third, the heterogeneity of prior treatments, time to implementation of systemic $\mathrm{TH}$, and variable target temperature, time to target and duration of therapy at target leave the data on seizure responsiveness difficult to interpret. Fourth, the potential for publication bias in the articles reviewed is high. It is likely that only those cases displaying positive results after systemic TH treatment have appeared in the literature. Fifth, even though burst suppression appears attainable in some of these cases of RSE, this treatment provides only a means to achieve seizure control, with the transition to oral medication still required. Despite these limitations, we believe the data provides evidence for the potential benefit of systemic $\mathrm{TH}$, in both the adult and pediatric RSE populations.

We believe this systematic review provides a good reference for the use of systemic TH in RSE. Consideration should be made for future prospective study of TH in RSE. Upon publication of the two ongoing prospective trials utilizing TH in RSE, our ability to comment more definitively on the role of this technique should improve. However, regardless of the results of these trials, the small number of cases identified in this review highlights the need for multi-center databases for RSE in order to better outline the role of non-conventional therapies.

\section{Conclusions}

There currently exists Oxford level 4, GRADE D evidence to support the use of systemic TH to achieve seizure reduction in RSE. Further prospective study of systemic TH in RSE is warranted.

\section{Disclosure}

Fred Zeiler has the following disclosures:

Health Sciences Center Foundation, Researcher, Research grant for project on optic nerve sheath diameter. Kaitlin Zeiler, Jeanne Teitelbaum, Lawrence Gillman, and Michael West do not have anything to disclose.

\section{SUPPLEMENTARY MATERIAL}

To view supplementary material for this article, please visit http://dx.doi.org/10.1017/cjn.2015.31

\section{REFERENCES}

1. Kamps MJ, Horn J, Oddo M, et al. Prognostication of neurologic outcome in cardiac arrest patients after mild therapeutic hypothermia: a meta-analysis of the current literature. Intensive Care Med. 2013;39:1671-82.

2. Alkarfy TM. Induced hypothermia to treat neonatal hypoxic-ischemic encephalopathy. Review of literature with meta-analysis and development of national protocol. Neuroscience (Riyadh). 2013;18:18-26.

3. Sandestig A, Romner B, Grande PO. Therapeutic Hypothermia in Children and Adults with Severe Traumatic Brain Injury. Ther Hypotherm Temp Manag. 2014;4:10-20.

4. Wu TC, Grotta JC. Hypothermia for acute ischaemic stroke. Lancet Neurol. 2013;12:275-84.
5. Rivera-Lara L, Zhang J, Muehlschledel S. Therapeutic hypothermia for acute neurological injuries. Neurotherapeutics. 2012;9:73-86.

6. Motamedi GK, Lesser RP, Vicini S. Therapeutic brain hypothermia, its mechanisms of action and its prospects as a treatment for epilepsy. Epilepsia. 2013;54:959-70.

7. Rossetti AO. What is the value of hypothermia in acute neurologic diseases and status epilepticus. Epilepsia. 2011;52(Suppl. 8):64-6.

8. Kowski AB, Kanaan H, Schmitt FC, Holtkamp M. Deep hypothermia terminates status epilepticus - an experimental study. Brain Res. 2012;1446:119-26.

9. Cereda C, Berger MM, Rossetti AO. Bowel ischemia: a rare complication of thiopental treatment for status epilepticus. Neurocrit Care. 2009;10:355-8.

10. Corry JJ, Dhar R, Murphy T, Diringer MN. Hypothermia for refractory status epilepticus. Neurocrit Care. 2008;9:189-97.

11. Czeisler BM, Manvar SM, De Marchis GM, et al. Temperature modulation for refractory status epilepticus: normothermia and hypothermia. Neurocrit Care. 2013;19(Suppl. 1):S278.

12. Elting JW, van der Naalt J, Fock JM. Mild hypothermia for refractory focal status epilepticus in an infant with hemimegalencephaly. Eur J Paediatr Neurol. 2010;14:452-5.

13. Guilliams K, Rosen M, Buttram S, Zempel J, Pineda J, Miller B, et al. Hypothermia for pediatric refractory status epilepticus. Epilepsia. 2013;54:1586-94.

14. Hakimi R, Talsania S, Fesler JR, Fields E. Does the efficacy of therapeutic hypothermia in refractory status epilepticus depend on seizure etiology? Neurocrit Care. 2013;19(Suppl. 1):S218.

15. Ito H, Mori K, Toda Y, Sugimoto M, Takahashi Y, Kuroda Y. A case of acute encephalitis with refractory, repetitive partial seizures, presenting autoantibody to glutamate receptor Glu-epsilon-2. Brain Dev. 2005;27:531-4.

16. Lin JJ, Lin KL, Hsia SH, Wang HS. Therapeutic hypothermia for febrile infection-related epilepsy syndrome in two patients. Pediatr Neurol. 2012;47:448-50.

17. Missert MJ, Qazi KJ, Ionita CC. Utilising therapeutic hypothermia in the control of non-convulsive status epilepticus in a patient with Creutzfeldt-Jakob encephalopathy. BJMP. 2012;5:a515.

18. Orlowski JP, Erenberg G, Lueders H, Curse RP. Hypothermia and barbiturate coma for refractory status epilepticus. Crit Care Med. 1984;12:367-72.

19. Shein SL, Reynolds TQ, Gedela S, Kochanek PM, Bell MJ. Therapeutic hypothermia for refractory status epilepticus in a child with malignant migrating partial seizures of infancy and SCN1A mutation. Ther Hypotherm Temp Manag. 2012;2:144-9.

20. Svoronos A, Kilbride RD, Mendoza L, et al. Non-traditional therapies for prolonged refractory status epilepticus: a multicenter review. Epilepsy Currents 2012; 12 Suppl. 1):3.211.

21. Vastola EF, Homan R, Rosen A. Inhibition of focal seizure a clinical and experimental study. Arch Neurol. 1969;20:430-9.

22. Higgins JPT, Green S, editors. Cochrane Handbook for Systematic Reviews of Interventions Version 5.1.0. http:handbook.cochrane. org. Accessed March 10, 2014.

23. Moher D, Liberati A, Tetzlaff J, Altman DG, Group P. Preferred reporting items for systematic reviews and meta-analysis: the PRISMA statement. Ann Intern Med. 2009;151:264-9.

24. Phillips B, Ball C, Sackett D, Straus S, Haynes B, Dawes M. Oxford Centre for Evidence-Based Medicine Levels of Evidence. Version 2009. http://www.cebm.net/?o=1025. Accessed March, 2014.

25. Guyatt GH, Oxman AD, Vist G, et al. Rating quality of evidence and strength of recommendations GRADE: an emerging consensus on rating quality of evidence and strength of recommendations. BMJ. 2008;336:924-6.

26. Guyatt GH, Oxman AD, Kunz R, Vist GE, Falck-Ytter Y, Schünemann HJ, et al. Rating quality of evidence and strength of recommendations: What is "quality of evidence" and why is it important to clinicians? BMJ. 2008;336:995-8.

27. Schünemann HJ, Oxman AD, Brozek J, et al. Grading quality of evidence and strength of recommendations for diagnostic tests and strategies. BMJ. 2008;336:1106-10.

28. Guyatt GH, Oxman AD, Kunz R, et al. Rating quality of evidence and strength of recommendations: Incorporating considerations of resources use into grading recommendations. BMJ. 2008;336:1170-3. 
29. Guyatt GH, Oxman AD, Kunz R, Falck-Ytter Y, Vist GE, Liberati A, et al. Rating quality of evidence and strength of recommendations: Going from evidence to recommendations. BMJ. 2008;336:1049-51.

30. Jaeschke R, Guyatt GH, Dellinger P, et al. Use of GRADE grid to reach decisions on clinical practice guidelines when consensus is elusive. BMJ. 2008;337:a744.

31. Assistance Publique - Hôpitaux de Paris. Evaluation of the interests of a therapeutic hypothermia procedure in convulsive status EPILEPTICUS in adults in intensive care - HYBERNATUS study. In: ClinicalTrials.gov [Internet]. Bethesda (MD): National Library of Medicine (US). 2000-[cited 2014 May 12]. Available from: http://clinicaltrials.gov/show/NCT01359332 NLM Identifier: NCT01359332.

32. Xuanwu Hospital, Capital Medical University. Simultaneous combination of anesthetic and hypothermia to treat refractory status epilepticus. In: http://apps.who.int/trialsearch/Default.aspx
[Internet]. Geneva (Switzerland). 1994-[cited 2014 May 12]. Available from: http://apps.who.int/trialsearch/Trial.aspx?Trial ID=ChiCTR-TRC-14004508 Main ID: ChiCTR-TRC-14004508. 33. Volgushev M, Vidyasagar TR, Chistiakova M, Yousef $T$, Eysel UT. Membrane properties and spike generation in rat visual cortical cells during reversible cooling. J Physiol. 2000;522: 59-76.

34. Boucher J, Kroger H, Sik A. Realistic modelling of receptor activation in hippocampal excitatory synapses: analysis of multivesicular release, release location, temperature and synaptic crosstalk. Brain Struct Funct. 2010;215: 49-65.

35. Yang XF, Ouyang Y, Kennedy BR, Rothman SM. Cooling blocks rat hippocampal neurotransmission by a presynaptic mechanism: observations using 2-photon microscopy. J Physiol. 2005;567:215-24. 